\title{
OVERVIEW OF WORKERS' PULMONARY FAAL CONDITIONS AND WORKER ACTIONS AT THE END OF THE FINAL SCRUB INDUSTRY X SURABAYA
}

\author{
Maya Puspita Sari, Corie Indria Prasasti \\ Depertment of Enviromental Health, \\ Faculty of Public Health, Airlangga University, Surabaya, Indonesia \\ Correspondence Address: Maya Puspita Sari \\ Email: mayapuspita751@gmail.com
}

\begin{abstract}
One type of air pollution that has the potential to harm human health is particulate dust. Particulate dust causes pulmonary damage when inhaled during work continuously. The purpose of this study was to see the description of the condition of the lung physiology, workers' actions, worker smoking habits, use of respiratory tract,and physical quality of the environment. This was descriptive research, using design cross-sectional. The sample size used total population as 14 people. physical environmental quality includes $\mathrm{PM}_{2.5}$ concentration, air temperature and humidity. The action variable was measured using an observation sheet, while smoking habits and respiratory tract measured using a questionnaire. Lung function disorder was measured using spirometry. Based on the results, $50 \%$ of workers had a bad action, $64.3 \%$ of workers had a smoking habit, and $28.6 \%$ of workers didn't use continuous respiratory protection during working hours. The measurement of physical environmental quality at $\mathrm{PM}_{2.5}$ still meets the quality standard, while for the temperature and humidity do not meet quality standards. A total of 5 workers in the final rub section have lung function disorders. The conclusion that can be taken is more lung function disorder is experienced by workers who have smoking habits, not using continuous respiratory protection during working hours. The advice that can be given is that the use of the respiratory protector of masks should always be used continuously while workin. For workers with lung function disorders, should immediately conduct further medical examination and reduce smoking habits so that the lung physiological condition doesn't decrease.
\end{abstract}

Keywords: $\mathrm{PM}_{2.5}$ concentration, lung function disorders, workers' actions, worker smoking habits, use of respiratory protection

\section{ABSTRAK}

Salah satu jenis pencemaran udara yang mempunyai potensi membahayakan kesehatan manusia adalah partikulat debu. Partikulat debu menyebabkan kerusakan pada faal paru apabila terinhalasi selama bekerja secara terus menerus. Tujuan penelitian ini untuk melihat gambaran mengenai kondisi faal paru, tindakan pekerja, kebiasaan merokok pekerja, penggunaan alat pelindung saluran pernapasan, dan kualitas fisik lingkungan kerja. Penelitian ini merupakan jenis penelitian deskriptif, dengan menggunakan desain studi cross-sectional. Besar sampel penelitian ini menggunakan total population sebanyak 14 orang. Variabel kualitas fisik lingkungan yang diukur meliputi kadar PM, 2,5 shu udara dan kelembaban. Variabel tindakan diukur menggunakan lembar observasi, sedangkan kebiasaan merokok dan penggunaan alat pelindung saluran pernapasan diukur menggunakan kuesioner. Gangguan faal paru pekerja diukur menggunakan alat spirometer. Berdasarkan hasil penelitian, Sebanyak 5 pekerja di bagian gosok akhir mengalami gangguan faal paru. Terdapat 50\% pekerja memiliki tindakan yang kurang baik, 64,3\% pekerja di bagian gosok akhir memiliki kebiasaan merokok dan 28,6\% pekerja tidak menggunakan pelindung saluran pernapasan secara terus-menerus selama jam kerja. Pengukuran kualitas fisik lingkungan pada kadar PM, $M_{2,5}$ masih memenuhi baku mutu,sedangkan untuk suhu dan kelembaban tidak memenuhi baku mutu. Kesimpulan yang dapat diambil adalah gangguan faal paru lebih banyak dialami oleh pekerja yang memiliki kebiasaan merokok,dan tidak menggunakan pelindung saluran pernapasan secara terusmenerus selama jam kerja. Saran yang dapat diberikan yaitu penggunaan pelindung saluran pernapasan berupa masker harus selalu digunakan secara terus menerus pada saat bekera. Bagi pekerja yang mengalami gangguan faal paru, sebaiknya segera melakukan pemeriksaan kesehatan lebih lanjut, serta mengurangi kebiasaan merokok agar kondisi faal paru tidak menurun.

Kata kunci: kadar $P M_{2,5}$, tindakan pekerja, kebiasaan merokok, penggunaan pelindung saluran pernapasan, gangguan faal paru 


\section{INTRODUCTION}

Air is one of the very important environmental elements, hence is a way to maintain its quality in order to provide support to living creatures to the fullest. In the current era, industry developments in Indonesia are increasing rapidly. The consequence of the development of this industry is by producing more waste, including air waste that can change the quality of ambient air and air in the room.

According to (Mukono, 2008) it is said that air pollution is an added ingredient in the normal air environment that can be measured by humans that can cause disruption to living creatures. Air pollutants produced from industries are particulate, sulfur dioxide (SO2), nitrogen dioxide (NO2), Carbonmonoxide (CO) gas, ammonia gas (NH3) and hydrocarbon gas (HC) (Mukono, 2008). If there is an increase in the levels of these materials in the air that exceed the quality standard value set, it can cause health problems in humans.

The negative impact that occur is the emergence of diseases caused by work exposed to chemicals during the production process. The emergence of illness from work according to presidential decree number 22 year 1993 stipulates there are 31 types of diseases arising from work. Organs and body systems that are widely affected by exposure to hazardous substances in the workplace, such as lung organs and respiratory tract systems. Lung diseases caused by work are pulmonary abnormalities arising from inhaling particles, gases, vapors that are harmful during the work, so it will be buried and accumulated in the human respiratory tract.

According to (Suma'mur., 2001) mentions that occupational safety is a form of activity to create a comfortable and safe working atmosphere for workers working in the company. In order to create such conditions necessary elements on occupational safety and Health, among others, the presence of personal protective equipment, the Regulation and division of duties, as well as the working environment in accordance with the standards of working environment requirements.

The purpose of occupational safety and health in the working environment is to ensure the safety and health of workers from potential accidents and occupational diseases. A working environment with high dust levels can cause disturbance to work comfort and can slowly cause interference with the respiratory tract. Interference with the respiratory tract can be caused by dust, gas, smoke that is inhaled by workers in the workplace. One type of air pollution that has potential toharm human health is particulate. The dust particulate comes from a solid, liquid-shaped particle that is in the air.

By its size, the Environmental Protection Agency (EPA), dust is grouped into 2 categories, namely dust particles $\leq 10$ micrometers (PM10) and dust particles $\leq$ 2.5 micrometers (PM2, 5). The particle size directly causes a potential health problem. Particles that have a diameter of $\leq 10$ micrometers can cause problems, because they can enter the lungs and can even enter the bloodstream. Quality raw environment based on Ministry of Health Minister of Republic of Indonesia No. 70 year 2016 on standards and health requirements of industrial work environment that the standard of dust quality in a working environment in the industry for 8 hours IE $10 \mathrm{mg} / \mathrm{m} 3$.

The level of dust that exceeds the quality of the environment will have a risk affecting human health disorders. According to the research conducted by (Rixson, L., dan Riani, 2015), the source of air pollution originating from PM 2.5 comes from several sectors of the industry, among others, the transportation sector $(44.36 \%)$, the metal smelting industry $(9.61 \%)$, the soil dust mixture (17\%), A mixture of metal smelting and sea salt (13.02\%), and biomass combustion $(22.58 \%)$. The rate of PM2, 5 which is in the air can affect human health when inhalation. The concentration of PM2, 5 of which is inhalation, will be entered into 
the alveoli, causing abnormal pulmonary conditions that may result in limited pulmonary power (Rahardjo, 2010). One of the negative impacts caused by the exposure of PM 2.5 is the decline in lung function in humans. Decreased pulmonary function can be an indicator of determining chronic respiratory tract infections in humans.

Surabaya City is one of the cities in Indonesia with a rapidly growing industrial sector. Surabaya has an industrial area located in the area of Margomulyo. In this area there are many kinds of industrial sectors, such as heavy metal processing industry, heavy equipment industry, construction industry, and warehousing area. This industrial area in Margomulyo is one of the areas that contributes to air pollution in the environment. Industri $X$ Surabaya is an industry located in the area of Margomulyo. Industri X Surabaya is a manufacturing vehicle that manufactures rim for four-wheeled vehicles made from aluminium raw materials.

This research is done in one of the industries in the area of Margomulyo Surabaya. Based on an introductory survey, there are most aluminum dust density found in the final scrub section of Industri $X$ Surabaya. This is because the process of scrubbing is entirely done manually by the worker using a scratch paper that is attached to the machine.

So that the dust resulting from this process of the scrubbing can be directly inhalation by the worker. The final scrub is one of the toolsto make the surface of the rim smoother by rubbed-rubbing on the surface of the rim before going into the next process of painting. In addition, based on the observation conducted by researchers and interviews with supervisors, it is known that the industry has stood for approximately 22 years.

In addition, there are some workers who complain of respiratory tract disorders such as coughs in the workplace. This research aims to see the idea of worker action, smoking habit of using respiratory tract protective equipment, the physical quality of working environment and the condition of lung Faal experienced worker in the end of the scrub industry X Surabaya.

\section{METHODS}

The research was conducted in the final scrub section of industry $\mathrm{X}$ car Surabaya. This research is an observational research because the data is derived from the results of measurements, observations, and interviews directly at the research site. The study are adescriptive study, using a cross-sectional design. The research site is the wheel industry in Margorejo area, Surabaya.

The research time began in November 2017 until June 2018. The population in this study is all workers working in the final scrub section of the industrial rim of Surabaya, as much as 14 people. The physical quality measurements of the environment consist of PM level 2.5 which is measured using the EPAM 5000 tool, then the temperature and humidity measured using a thermohygrometer tool.

Measuring the condition of the lung faal is carried out using Spirometer. Smoking habits and use of respiratory tract protectors are measured using questionnaire sheets, as well as worker actions measured using an observation sheet. This research has obtained approval from the Health Research Ethics Commission team of the Faculty of Public Health, Airlangga University, certificate number: 236-KEPK. The data analytic technique of the study uses descriptive analysis methods and crosstab analysis. Descriptively analyzed variables are worker action, smoking habit, use of respiratory tract protectors, environmental physical factors, PM level 2.5 and worker's pulmonary faal condition. After the data is collected, the data analysis is then performed descriptively by describing the subjects that are researched and presented in narrative form. This research has obtained a description of the passing of the Ethics Commission FKM No: 236-KEPK. 


\section{RESULT}

\section{Overview of Industrial X Surabaya}

Industri $\mathrm{X}$ Surabaya is a manufacturing company that manufactures rim/aluminium wheel for four-wheeled vehicles or passenger cars made from aluminium raw materials. The production process consists of the process of receiving raw materials, smelting aluminum material raw materials, printing process, X-ray inspection process, cutting process, heat treatment process/expansion, sand blasting process, fertilizing process, drilling process, Balancing process, leak test process, washing process, powder coating process, final scrub process, painting process, final checking process, and packing and shipment process. Based on preliminary research, obtained by aluminium dust density is the most found in the final scrub section of Industri X Surabaya.

This is because the process of scrubbing is entirely done manually by the worker. The final scrub process is one of the tools needed to make the wheel surface smoother by rubbed the surface of the wheel before going into the next process of painting. In this industry the final scrub process is done manually by workers. The working hours of workers in the final scrub start at 08.00-16.00. The company has stood for approximately 22 years.

Results of measurement of lung Faal at end of industrial scrub Section $X$ Surabaya

Measurement of lung faal on workers in industry X Surabaya by using Spirometer tool. The measurement of lung faal on workers is performed at the end of the production process, and will be known as description of the condition of the lung faal with normal pulmonary faal condition, and abnormal pulmonary faal condition. Abnormal pulmonary faal conditions are divided into restrictive, obstructive, and mixed (restrictive and obstructive). There is a degree of severity in workers who have impaired pulmonary faal, which is the degree of mild, moderate, and severe severity. The following are the results of measurements using the spirometer performed on workers in the final scrub section of Industri X Surabaya:

Table 1. Respondents distribution based on pulmonary Faal conditions at the end of the industry $\mathrm{X}$ Surabaya Industrial Year 2018

\begin{tabular}{lccc}
\hline $\begin{array}{l}\text { Pulmonary } \\
\text { Conditions }\end{array}$ & Faal & n & $\mathbf{( \% )}$ \\
\hline Normal & & 9 & 64,3 \\
\hline Upnormal & & 35,7 \\
Restriktif & 5 & \\
Obstruktif & & \\
Mix & & \\
\hline Total & & $\mathbf{1 4}$ & $\mathbf{1 0 0}$ \\
\hline
\end{tabular}

Table 2. Distribution of respondents based on worker actions, smoking habits and use of worker respiratory tract protectors at the end of the Industrial scrub Section $\mathrm{X}$ Surabaya year 2018 .

\begin{tabular}{ll}
\hline & \multicolumn{2}{c}{ Total } \\
\cline { 2 - 3 } Variable & $\mathrm{n} \quad \%$
\end{tabular}

\begin{tabular}{lcc}
\hline $\begin{array}{l}\text { Worker actions } \\
\text { Good }\end{array}$ & 12 & 85,7 \\
$\quad$ Not Good & 2 & 14,3 \\
\hline Habit of smoking & & \\
$\quad$ Smoking & 9 & 64,3 \\
$\quad$ No Smoking & 5 & 35,7 \\
\hline Respiratory Tract Shield & & \\
use & 10 & 71,4 \\
$\quad$ Always & 4 & 28,6 \\
$\quad$ Sometimes &
\end{tabular}

be noted that, from 14 workers in the final scrub industry $\mathrm{X}$ Surabaya, there are 5 workers who have abnormal pulmonary faal condition. The worker has a restrictive pulmonary faal disorder with a mild degree of severity and 9 other workers have a normal pulmonary faal condition. 


\section{Action worker at end of industrial scrub Section X Surabaya}

In the worker action variables in the final scrub section of Industri X Surabaya measured using an observation sheet with several questions, covering the presence of periodic dust measurements, the presence of masks at work, masks are always used when working, Masks are used cleanly, regular health screening, working while smoking, cleaning yourself up when done working, and changing work clothes every day.

The results of the measurements then categorized into good and less good. The category is good if the value $>60 \%$ of the average worker action, while the category is less good if the value is $\leq 60 \%$ of the average worker action. Based on the table above, it is known that from 14 workers in the final scrub industry $\mathrm{X}$ Surabaya, there are 7 workers have less good action (50\%), while the rest have good action. Based on the observation result, the worker's actions include respiratory tract protectors in the workplace, not smoking at work, cleaning themselves when finished working, and changing clothes every day. While workers who have less good actions are influenced by several factors, namely the absence of periodic dust measurement, masks are not always used when working, masks look dull and shabby but still in use, as well as absence of Regular health screening.

\section{Smoking habits in the final scrub industry X Surabaya}

The habit of smoking on workers in the final scrub section of Industri $\mathrm{X}$ Surabaya uses a questionnaire sheet. The habit of smoking workers is categorized as light, moderate and heavy smokers by using the Brinkman (IB) index formula, which is the number of cigarettes sucked in a day in the trunk unit by the time of smoking in the year, then categorized In accordance with IB which is light smoker when having IB = $0-200$, Smoker is medium if have IB $=201$ 600 and heavy smoker if have IB $=>600$. Based on the table above, it can be noted that the workers in the final scrub industry X Surabaya, which has a habit of smoking amounted to 9 workers $(64.3 \%)$, while workers who do not have a smoking habit of 5 respondents $(42.9 \%)$.

Table 3. Cross tabulation between worker action, smoking habit and use of respiratory tract protectors with Labor Faal in the final scrub section in Industry X Surabaya year 2018

\begin{tabular}{|c|c|c|c|c|c|c|}
\hline \multirow{3}{*}{ Variable } & \multicolumn{4}{|c|}{ Worker's lung Faal } & \multicolumn{2}{|c|}{ Total } \\
\hline & \multicolumn{2}{|c|}{ Normal } & \multicolumn{2}{|c|}{ Upnormal } & \multirow[b]{2}{*}{$\mathrm{n}$} & \multirow{2}{*}{$\%$} \\
\hline & $\mathrm{n}$ & $\%$ & $\mathrm{n}$ & $\%$ & & \\
\hline \multicolumn{7}{|l|}{ Worker actions } \\
\hline Good & 7 & 58,3 & 5 & 41,7 & 12 & 100 \\
\hline Not Good & 2 & 100 & 0 & 0 & 2 & 100 \\
\hline \multicolumn{7}{|l|}{ Habit of smoking } \\
\hline Smoking & 5 & 55,6 & 4 & 44,4 & 9 & 100 \\
\hline No Smoking & 4 & 80 & 1 & 20 & 5 & 100 \\
\hline \multicolumn{6}{|c|}{ Respiratory Tract Shield use } & \\
\hline \multirow{2}{*}{$\begin{array}{l}\text { Always } \\
\text { Sometimes }\end{array}$} & 7 & 70 & 3 & 30 & 10 & 100 \\
\hline & 2 & 50 & 2 & 50 & 4 & 100 \\
\hline
\end{tabular}


According to the table above, 4 workers who have good actions tend to suffer from pulmonary faal disturbance of $58.3 \%$. While 1 worker who has a less good action $85.7 \%$ experienced normal pulmonary faal condition. There are 4 workers with good actions that have a lung Faal disorder that has a working period of more than 10 years.

Based on the table above, showed that $44.4 \%$ of workers who have abnormal pulmonary faal condition are more experienced by smoking worker. While $80 \%$ of workers who do not smoke tend to have normal pulmonary faal conditions. So there is a relationship between the habit of smoking with the disturbance of lung Faal on the end of the working part of Industri X Surabaya.

Furthermore, based on the table above, most workers who have abnormal pulmonary faal condition are those who does not always use the respiratory protection continuously at the time of work, that is as much as $50 \%$. While $70 \%$ of workers who always use respiratory tract protectors tend to have normal pulmonary faal conditions.

So there is a connection between the use of respiratory protection with pulmonary disturbance in the end of the workers at Industri X Surabaya industry. There are 2 workers who always use the respiratory protection during working hours but have a disturbance of pulmonary faal, it is because the worker has been working for more than 10 years, as well as one worker has an age of 40-49 years and has a habit Smoking.

\section{Use of respiratory tract protective equipment in the end of the scrub industry X Surabaya}

Based on table 2 workers in the final scrub section of Industri X Surabaya who always use the respiratory protection device in the form of a continuous mask of 10 workers $(71.4 \%)$ And which is not always used when working for 4 workers $(28.6 \%)$. Workers who do not always use respiratory protective equipment in the form of masks are workers who feel disturbed and uncomfortable to use a respiratory protective equipment in the form of masks. However, in the end of the working environment condition of industrial $\mathrm{X}$ Surabaya is very dusty, workers who do not always use the respiratory protection device will immediately use the mask back. And there is a penalty for workers when not wearing a breathing apparatus that is a strike by the foreman in the field

\section{Results of physical quality measurement of working environment}

Measuring PM 2.5 is done on a onetime basis, namely during the process of scrubbing. Measurement of PM 2.5 this uses the EPAM 5000 tool. In the results of the measurement of PM 2.5 by using EPAM 5000 will be obtained rate PM 2.5 per minute. The time required to measure the rate of PM 2.5 is 30 minutes starting at 11.01 until 11.31 WIB.

So within 30 minutes will get 30 times the recording of measurement results of PM 2.5 on the environment. The recording rate of PM 2.5 per-minute will be obtained maximum, minimum, and average of PM 2.5 at the end of industrial $\mathrm{X}$ Surabaya scrub environment.

Recording PM 2.5 is depicted in graphic form. It is done to know the value of each minute. The following are the results of environmental physical quality measurements consisting of PM 2.5, temperature, and humidity levels in the final scrub section of Industri X Surabaya. 


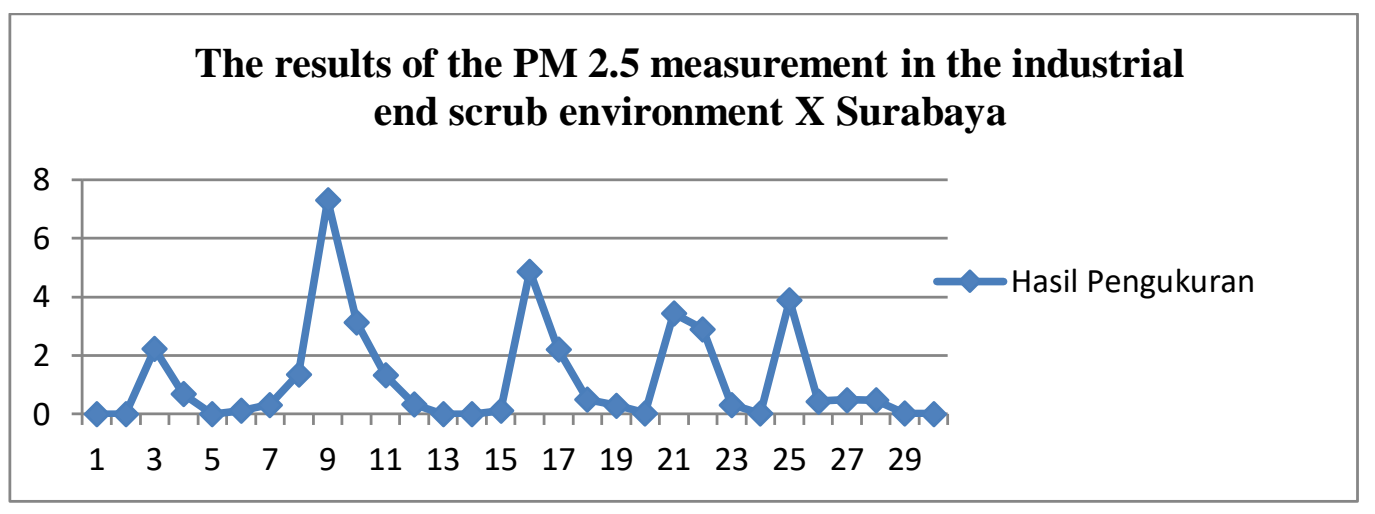

Pictures 1. Graphs of measurement results of PM 2.5 parts final scrub industry X Surabaya

The results of the PM 2.5 measurements of the final scrub environment have unstable or volatile results, of which PM 2.5 in the working environment of the final scrub industry $\mathrm{X}$ Surabaya are not fixed and always changing.

Based on the chart above, it can be noted that in the $3 \mathrm{rd}$ minute $\left(2.233 \mathrm{mg} / \mathrm{m}^{3}\right)$, the 9 th minute $(7.311 \mathrm{mg} / \mathrm{m} 3)$, the 16 th minute $\left(4.873 \mathrm{mg} / \mathrm{m}^{3}\right)$, the $21 \mathrm{st}$ minute $\left(3,428 \mathrm{mg} / \mathrm{m}^{3}\right)$, the 25 th minute $(3,880$ $\left.\mathrm{mg} / \mathrm{m}^{3}\right)$ is experiencing a drastic increase from the previous minute.

This can happen because at that time all the workers in the final scrub section of Industri X Surabaya undertook the process of scrubbing on the surface of the rim together. Therefore, the dust that is removed from the process of scrubbing on the surface of the rim becomes more numerous. In the 9th minute is the highest point in the measuring result chart, where the measured $\mathrm{PM}$ rate of 2.5 is $7.311 \mathrm{mg} / \mathrm{m}^{3}$.

Table 4. Results of measurement of physical factors of industrial environment X Surabaya in the rub end of year 2018

\begin{tabular}{lcccc}
\hline \multirow{2}{*}{ Location } & \multicolumn{2}{c}{ Rate of $\mathbf{P M}_{2,5}$} & Tem & \\
\cline { 2 - 3 } & Maks & $\begin{array}{c}\text { Avera } \\
\text { ge }\end{array}$ & $\begin{array}{c}\text { pera } \\
\text { ture }\end{array}$ & Moisture \\
\hline $\begin{array}{l}\text { Final } \\
\text { Scrub }\end{array}$ & 7,311 & 1,471 & & \\
Section & $\mathrm{mg} / \mathrm{m}^{3}$ & $\mathrm{mg} / \mathrm{m}^{3}$ & & \\
\hline
\end{tabular}

Based on the above results it can be known that the maximum and average level of PM 2.5 in the final scrub when the production process still meets the quality of the environment based on the (Regulation of the Minister of Manpower and Transmigration of the Republic of Indonesia, 2016) About the standard and health requirements of industrial work environment is $10 \mathrm{mg} / \mathrm{m}^{3}$.

While the temperature in the final scrub does not qualify (Decree of the Minister of Health of the Republic of Indonesia, 2002) about the health requirements of office and industrial work of $18-300 \mathrm{C}$. The humidity in the final scrub is also ineligible at $65-95 \%$.

\section{DISCUSSION}

The depiction of a lung Faal and worker action at the end of industry $X$ Surabaya

The measurement of lung Faal on workers is performed at the end of production process. Before the measurement, workers were given an explanation of the procedure of lung Faal measurement one day before. From the results of the research it obtained 5 respondents who have a pulmonary faal disorder with a degree of mild severity. One of the factors that can cause a lung faal on a worker is dust.

Dust in the working environment is thought to be a potential factor that can cause disturbance in the workers ' lung Faal (Pasaribu, 2017). In the restriction conditions FEV1 and FVC values will decrease, while the normal FEV1/FVC value will be increased. Restriction of 
pulmonary Faal disorders can be known by reduced pulmonary volume caused by allergenic materials such as spores, fungi and dust (Lestari, 2010). Industrial X Surabaya that produces rim can produce PM2, 5 with high enough content that can be one of the causes of restrictive lung Faal disorder in workers.

Occupational illness is a risk that workers have to bear during work in an industry. The emergence of occupational diseases can be caused due to the working area condition that has potential dangers that exceed the threshold value has been determined. Based on the observation results of respondents who have a less good action influenced by several factors: the absence of periodic dust measurements, masks are not always used when working, masks used are not clean or masks are already Look dull and shabby but still used, and lack of medical examinations at least 6 months.

The results of the analysis show that workers who have good actions tend to experience abnormal pulmonary faal conditions of $41.7 \%$. While at workers who have a less good action $100 \%$ have a normal pulmonary faal condition. Therefore, there is no link between the action of workers and the disturbance of pulmonary faal at the end of the final scrub industry X Surabaya.

\section{Smoking habits in the final scrub industry X Surabaya}

Respondents who have a smoking habit of 6 people enter the category of lightweight smokers using the Brinkman index (IB) 0-200, among others, 162, $130,195,176$, and 150 . While 3 others are categorized as medium smoker with each Brinkman index of 225, 420, and 550. The larger the IB number, the higher the occurrence of pulmonary faal disorder. This can happen, due to the many harmful substances from cigarette smoke that enter the human body so that it can disrupt the respiratory system into the lungs.
Usage of respiratory tract protective equipment in the end of the scrub industry X Surabaya

The usage of the respiratory tract protector in the form of a mask on the end of the scrub industry X Surabaya is an effort to reduce the inclusion of dust particles into the respiratory tract. By using the mask, it is expected to protect itself from dust exposure in the working environment. However, there is no guarantee that workers using masks will avoid possible breathing disorders.

The usage of respiratory tract protectors at the end of industrial $\mathrm{X}$ Surabaya using disposable masks. This mask is generally green in color, and there is a penalty for workers when not wearing a mask that is a strike by a foreman in the field. According to regulation of the Minister of Manpower and transmigration of Republic of Indonesia No. 08 year 2010 about Personal protective equipment, is a tool that has the ability to protect someone while working which serves to close half or all Labor from the dangers of the workplace.

\section{Measurement of physical quality of work environment in the end of scrub industry X Surabaya}

The final scrub process in industrial $\mathrm{X}$ Surabaya becomes one of the main sources of the particulate dust. The particulate dust that resides in the working environment will have a harmful impact on the body and can cause impaired lung faal when it is inhalation continuously during work.

Based on the results on environmental physical quality measurements consisting of $\mathrm{PM}_{2,5}$, air temperature and humidity in the working environment of the final scrub industry X Surabaya, the maximum rate of PM2, 5 in the final scrub section is 7.311 $\mathrm{mg} / \mathrm{m}^{3}$. So that the rate of $\mathrm{PM}_{2,5}$ in the final $\mathrm{scrub}$ is $10 \mathrm{mg} / \mathrm{m}^{3}$, it still meet the quality of the environment based on the regulation of the Minister of Health Republic of Indonesia number 70 year 2016 about the 
standards and health requirements of the industrial work environment. On the contrary, the temperature in the final scrub does not meet the quality of the environment from the (Decree of the Minister of Health of the Republic of Indonesia, 2002) about the health requirements of office and Industrial Work environment of 18-300C. And the humidity in the final scrub is also ineligible with the environmental quality standard of $65-95 \%$.

\section{Worker actions and employee Faal disorders}

Action is a person's activity that can be observed directly. The actions in this study are categorized into two namely good and less good deeds. Based on the results of the study shows that half of the workers in the final scrub section of Industri $\mathrm{X}$ Surabaya have good and less good action related to dust control in the working environment, as well as awareness to always use masks and Change the dirty mask in the workplace. So there are still workers in the final scrub that experience the disturbance of pulmonary faal.

This can be attempted so that the workers who have the disturbance of the lung Faal does not increase in the final scrub section of industrial X Surabaya is one of them by getting used to always use the respiratory tract protector in the form of particles the dust does not directly enter the respiratory tract. In this study it can be known that the end of the final scrub that has a good action tends to have abnormal pulmonary faal conditions. Meanwhile, the final scrub workers who have less good action tend to have normal pulmonary faal conditions.

Based on cross-tabulation results between workers lung Faal disorders with the end of working part of the final scrub in Industri $X$ Surabaya, descriptive disturbance of the lung Faal more experienced by workers who have good action, while workers The final scrub that has a less good action tends to have a normal pulmonary faal condition. Thus, in the results showed that there is no correlation between actions with the incidence of pulmonary faal disorder on workers in the final scrub section of Industri $\mathrm{X}$ Surabaya.

According to (Notoatmodjo, 2014) attitudes have not been a predisposition of action. This can happen because it can be influenced by some things: the situation at that time, the experience of others, the experience of oneself, and the value. If a person assesses the health of the lung Faal is not so important then the effort or action to prevent the occurrence of the disease will not be done. In addition, the supporting factors need to be able to create attitudes to be a real change, one of which is with facilities. In addition, it also takes support factors from various parties. For example from the officer, wife or husband, relatives, parents and others (Harianto, 2010).

\section{Habit of smoking workers and disorders of pulmonary Faal}

Based on the results of the cross tabulation of the outcome, workers with smoking habit more experienced lung faal than those who do not smoke. So there is correlations between the habit of smoking with the disturbance of lung Faal on the end of the working part of Industri X Surabaya.

Basically, the human lungs have elastic properties such as balloons, the lungs will expand when a person is breathing, and will decay when exhaling. Cigarette smoke has toxins that can reduce the elasticity condition of the human lungs. So that it can cause chronic pulmonary disease. It is very dangerous, because if it does not do the treatment to cope with the disease, then humans will slowly die from the lack of air when breathing (CDC, 2010). Toxins from cigarette smoke can reduce the elasticity of the human lungs, consequently a person will be attacked by chronic pulmonary disease. It is very dangerous, because there is no treatment to overcome this disease, and then a person will slowly die because of lack of air when performing breathing process (Sudrajad, 2016). 


\section{The usage of respiratory tract protectors and disorders of the pulmonary Faal}

From the results of the cross tabulation workers with pulmonary faal disorders are workers who do not always use the protective respiratory tract or not at the time of work. So there is a correlation between the use of respiratory protection with pulmonary disturbance in the end of the workers at Industri X Surabaya industry.

Research conducted by (Sormin, P., dan Kety, 2012) explained that there is a significant correlation between the use of masks with the incidence of acute respiratory infections in workers. In addition, research conducted by Yuliawat (2015) stated that workers who do not always use a protective equipment in the form of masks will be 44 times more severe pulmonary dysfunction compared with workers who always use tools Selfprotective mask. The most powerful reason underlying worker behavior when sometimes or not using persistent respiratory protectors at the time of work is that they feel uncomfortable to use respiratory tract protectors in the form of masks. Continuously.

Personal Protective Equipment has the ability to protect human beings in the work whose function isolates the body from danger in the work environment. So that the use of respiratory tract protectors must always be done in order to create safe and healthy conditions during work and to prevent more serious hazards that can threaten worker safety and health while working.

\section{Physical quality of environment and worker's lung Faal disorders}

The maximum rate of $\mathrm{PM}_{2,5}$ in the final scrub area is $7.311 \mathrm{mg} / \mathrm{m}^{3}$. So that the rate of $\mathrm{PM}_{2,5}$ on the environment in the final scrub still meet the quality of the environment based on the (Regulation of the Minister of Manpower and Transmigration of the Republic of Indonesia, 2016) about the standards and health requirements of industrial work of 10 $\mathrm{mg} / \mathrm{m}^{3}$. The process of scrubbing aluminum wheel becomes one of the main sources of particulate dust. The condition of exposure to dust in the working environment will have a harmful effect on the body, because the particulate dust can cause damage to the pulmonary faal when inhaled during continuous work.

According to research conducted by (Amaliyah, T., Russeng, S., dan Wahyu, 2013), stated that there is a corrwlation between the dust level and lung capacity in the employee. However, when the exposure of PM 2,5 still meets the quality standards of the environment and continues to be inhalation for many years may also cause the risk of pulmonary dysfunction and other respiratory diseases. This is because $\mathrm{PM}_{2,5}$ is one of the particulates that can enter the lungs.

Research conducted by (Keliat, Ermanta, 2016) states that the exposure to dust that has inorganic properties can cause restrictive lung faal disorders. The dust that is inhalation by the workforce can cause disturbance of the pulmonary faal. This can be proved by the number of workers who experience mild restrictive pulmonary Faal disorders as many as 5 people in the final scrub section of Industri X Surabaya which have high dust levels, high air temperature and low air humidity. Low humidity will support the formation of dust in the air.

One of the main factors that resulted in dust pollutants in the working environment of the final rub is from the process of scrubbing that is done manually by workers and lack of ventilation in the workplace, so that dust coming from the process of rubbing will be stuck and cannot escape freely from the work environment.

\section{CONCLUSION}

Based on the analysis process above, it can be concluded that workers in the end of the scrub industry X Surabaya have a normal lung condition and as many as 5 operators experience the disturbance of 
pulmonary faal blackberry with degrees of mild severity. The actions of workers have the same comparison between good and less good. Then workers have smoking habits, and workers always use persistent respiratory protectors.

Measuring the physical quality of the environment consisting of PM2, 5 still meets the quality standards of the Ministry of Health Regulation of the Republic of Indonesia number 70 year 2016 about the standard and health requirements of the industrial work environment. The disturbance of lung Faal is more experienced by the workers who have smoking habit, and do not always use the protection of the respiratory tract continuously at the time of work.

Suggestions that can be given based on the results that the use of respiratory guard in the form of mask correctly shouldbe used continuously at the time of Bekera. Workers who are suffering from lung Faal, should immediately conduct further health screening, maintain diet, reduce smoking habit so that the condition of pulmonary faal is not decreased.

\section{REFERENCE}

Amaliyah, T., Russeng, S., dan Wahyu, A., 2013. Hubungan Antara Kadar Debu dan Kapasitas Paru pada Karyawan PT. Eastern Pearl Flour Mills Makassar. Skripsi.Universitas Hasanuddin, Makassar.

CDC, 2010. A Report of the Surgeon General How Tobacco Smoke Causes Disease.

Harianto, R., 2010. Buku Ajar Kesehatan Kerja. Jakarta: EGC.

Keliat, Ermanta, F., 2016. Penyakit Paru Restriktif. Departemen Penyakit Dalam. Jurnal Penyakit Dalam Universitas Sumatera Utara.

Decree of the Minister of Health of the Republic of Indonesia Number 1405 of 2002 concerning Health Requirements for Office and Industrial Work Environments.
Jakarta: Minister of Health.

Lestari, A., 2010. Pengaruh Paparan Debu Kayu Terhadap Gangguan Fungsi Paru tenaga Kerja di Cv.Gion \& Rahayu, Kec. Kartasura, Kab. Sukoharjo Jawa Tengah. Skripsi. Universitas Sebelas Maret.

Mukono, J., 2008. Pencemaran Udara dan Pengaruhnya terhadap Gangguan Saluran Pernapasan. Surabaya: Airlangga University Press.

Notoatmodjo, S., 2014. Kesehatan Masyarakat Ilmu dan Seni Edisi Revis. Jakarta: Rineka Cipta. 138154.

Pasaribu, M., 2017. Hubungan Paparan Debu Las Dengan Gangguan Faal Paru Pada Pekerja Pengelasan Di Kelurahan Mesjid Kecamatan Medan Kota. Skripsi. Universitas Sumatera Utara.

c number 08 of 2010 concerning Personal Protective Equipment.

Rahardjo, R., 2010. Hubungan antara Paparan Debu Padi dengan Kapasitas Fungsi Paru Tenaga Kerja di Penggilingan Padi Anggraini, Sragen, Jawa Tengah. Skripsi. Universitas Sebelas Maret, Surakarta.

Rixson, L., dan Riani, E., 2015. Karakteristik Paparan Long Term Particulate Matter di Puspitek Serpong-Kota Tangerang Selatan. Jurnal Ilmiah Aplikasi Isotop dan Radiasi, 11(1). https://doi.org/10.17146/jair.2015.1 1.1.2703

Sormin, P., dan Kety, R., 2012. Hubungan Karakteristik dan Prilaku Pekerja yang Terpajan Debu Kapas dengan Kejadian ISPA di PT. Unitex Tahun 2011. Skripsi. Universitas Indonesia.

Sudrajad, M., 2016. Gambaran Status Faal Paru Pekerja di Industri Penggilingan Batu Kapur di Kabupaten Tuban. Jurnal Kesehatan Lingkungan, Universitas Airlangga, 8(2), pp.236-247. 
36 The Indonesian Journal of Public Health, Vol 15, No 1 April 2020:25-36

Suma'mur., 2001. Keselamatan Keja dan

Pencegahan Kecelakaan Kerja.

Jakarta : CV Haji Masagung. 